\title{
FOOD SECURITY INDICATORS IN UKRAINE: CURRENT STATE AND TRENDS OF DEVELOPMENT
}

\author{
Mykola Babych ${ }^{1}$, Anna Kovalenko² \\ Mykolayiv National Agrarian University, Ukraine
}

\begin{abstract}
The purpose of the paper is to study the current state of food security of Ukraine in order to identify the problem areas forming the system of food security in the country. Methodology. Assessment of the current state of the food security in Ukraine is carried out according to the Test Method for determining key indicators of food security, approved by the Cabinet of Ministers of Ukraine on 05.12.2007 № 1379 "Some Issues of Food Security" (as amended on 21.10.2011). Results. The article deals with the current state of food security in Ukraine for the next indicators: the daily energy value of the human diet, sufficiency consumption of certain products, the adequacy of supplies of grain in state resources, economic availability of food, differentiation value of food by social groups, market capacity of individual products, food self-sufficiency for a certain product. The study found that the state of Food Security in 2015 in Ukraine satisfied the set threshold values and rules by the majority of indicators. Practical implications. The value of particular indicators, calculated according to 2015 and compared to 1995, positively characterized the dynamics of food security in Ukraine. However, there is a necessity for a balanced state policy of the internal market and the agrarian sector's regulating. Value/originality. It is an obvious fact that it is needed to respect the objectives set out in the Strategy for Sustainable Development "Ukraine-2030" in the directions of development, security, responsibility, and pride.
\end{abstract}

Key words: food security indicators, diet, grain food resources, economic availability of products, market capacity, food independence, differentiation value of food.

JEL Classification: O13, P46, Q18

\section{Introduction}

The issue of food security is concerned with providing the population with the key food products in sufficient quantity and adequate quality, creation of state reserves and stocks of food and agricultural products of long periods of storage, as well as the timing of their safe export and import. Addressing these issues requires an integrated management of agriculture and the consumer market, application of modern tools and incentives, and improvement of the system of foodstuffs continuous quality control.

The formation of food security should be accompanied by monitoring organized by the nature of changes and their quantitative and qualitative assessments for the preparation of the appropriate guidelines and management decisions. As a result of monitoring, authorized executive authorities have to decide on changes in the food basket of basic social and demographic groups, and executive authorities have to decide on the changes and approve food kits to basic social and demographic groups (rada.gov, 2011).
In terms of European integration, providing transparency of internal and external food markets, constant monitoring of the indicators of food security becomes more and more necessary. Also, this will allow quickly respond to changes and generate corresponding public policies.

Talking about the monitoring indicators of food security, it should be allocated to the level where it is held: international, national, macro and micro level of households.

The monitoring of food security indicators at the international (global) level is exercised by FAO. Information on the evaluation methodology and indicators mentioned directly on the FAO's official site (FAO, 2017), which the organization brought together in a single database to provide an open access to information and creating a food security volume information system. Indicators classified by measuring four components of food security - availability, access, utilization, and stability. FAO is currently creating indicators for food safety and nutrition monitoring

\footnotetext{
Corresponding author:

${ }^{1}$ Department of Business Economics, Mykolayiv National Agrarian University.

E-mail: babichnn@i.ua

${ }^{2}$ Department of Business Economics, Mykolayiv National Agrarian University.

E-mail: KovalenkoAV@mnau.edu.ua
} 
(GSD 2) (FAO, 2016) under the new Global Agenda "Goals of Sustainable Development for 2016-2030".

The authoritative foreign researchers on the food security problems are Zhengxia Dou (2016), Kathryn J. Fiorella (2016), Sarina Macfadyen (2015), John Wilkinson (2015), Jessica Fanzo (2015), and others. However, these researchers did not conduct investigations of food security in Ukraine.

By the Cabinet of Ministers of Ukraine, the Resolution "Some Issues of Food Security” № 1379 dated 05.12.2007 (rada.gov, 2007) contained a list of tasks to the executive power to monitor indicators of food security of Ukraine at national, macro, and micro levels:

1) To the Ministry of Health, to determine every five years recommended by rational standards of consumption of basic products an average per one person;

2) To the Ministry of Agriculture and Food, the Ministry of Social Policy, and State Statistical Service, to provide within its authority submission to the Ministry of Economic Development and Trade every year until July 31 , the information necessary to calculate basic indicators of food security;

3) To the Ministry of Economic Development and Trade, to prepare and publish each year before $1^{\text {st }}$ September of the next period report on food security state in Ukraine.

On the official website of the Ministry of Economic Development and Trade of Ukraine, there is no report on food security in Ukraine for any period. Regarding food security published only the balance of demand and supply of meat and meat products, sugar, milk and dairy products, vegetable oils refined on 01.04.2015, the estimated balance of supply and demand of grain in $2014 / 2015$ marketing year by all categories of farms.

Over the last five years on the public domain (the official website of the Vernadsky National Library of Ukraine), there are more than twenty scientific works devoted to the study of indicators of food security of Ukraine. But, only three works of P. Sukhoi (2016), Krypa O., and Golikova K. (2013) analysed the most of the indicators of food security at the national level. Other authors, such as: Lisak M. (2013), Kotvytska N. (2012), Olefirenko T. (2013), Hryshova I. (2014), Chorna N. (2013) explore the dynamics of consumption of basic foodstuffs.

Some indicators of food security, according to the Methodology for Determining the Key Indicators of Food Security, approved by the Cabinet of Ministers of Ukraine "Some Issues of Food Security" (rada. gov, 2007), are available on the website of the State Statistics Service of Ukraine, but they are in different

\footnotetext{
${ }^{1}$ limit (threshold) criterion for this indicator is its $17 \%$ level corresponding to 60 days of consumption

${ }^{2}$ limit (threshold) criterion for this indicator is its 60-percent level
}

information sources, not structured and not are required interpretation to the public.

The monitoring of food security indicators at the households' level in Ukraine is not created.

\section{Materials and methods}

Assessment of the current state of food security in Ukraine performed according to test methods of basic indicators of food security, approved by the Cabinet of Ministers of Ukraine "Some Issues of Food Security" (rada.gov, 2007): the daily energy value of the human diet, sufficiency of consumption of certain products, the adequacy of supplies of grain in state resources, economic availability of food, differentiation value of food by social groups, market capacity of individual products, food self-sufficiency for a certain product.

The indicators of food security are:

1) daily energy value of the human diet, defined as the sum of products unit multiplications of certain types of foods that people consume during the day, and their energy value as follows:

\section{$E V=\Sigma m_{i} z_{i}$}

where $E V$ - energy value of the daily diet of a person; $i$ - a kind of foodstuff; $m_{i}$ - a mass of the $i$-product, consumed by a single person; $z_{i}$ - energy value per unit of mass of the $i$-product;

2 ) ensuring human diet with the main types of products, defined as the ratio between the actual consumption of the individual product and its rational norm by the formula:

$$
C=\frac{C_{f}}{C_{r}}
$$

where $C$ - consumption sufficiency indicator of a particular product; $C_{f}$ - actual consumption of single product per person per year; $C_{r}-$ rational individual product intake per person per year, agreed with the Ministry of Health;

3 ) the adequacy of supplies of grain in state resources, defined as the ratio between the amount of food grain in the state food reserve and volume of domestic consumption of bread and bread products in grain, equivalent to the following formula:

$$
G=\frac{H}{X}
$$

where $G$ - the indicator providing food grain resources; $N$ - availability of food grain in the state food reserve; $X$ - the average annual domestic consumption of bread and bread products in terms of grain ${ }^{1}$;

4) economic availability of products, defined as the share of total food expenses in the total aggregate household spending according to the formula:

$$
E=\frac{B_{x}}{B_{c}}
$$

where $E$ - an indicator of the economic availability of products; $B_{x}$ - expenditure on food per year; $B_{c}$ - total expenditure for the year ${ }^{2}$; 
5) differentiation of the value of food at social groups that monitored in dynamics and calculated as the ratio between the cost of food in 20 percent of households with the highest incomes and the cost of food in 20 percent of households with the lowest incomes according to the formula:

$$
D=\frac{D_{b}}{D_{m}}
$$

where $D$ - food value differentiation indicator; $D_{b}$ - index of value consumed in 20 percent of households with the highest income; $D_{m}$-index of value consumed in 20 percent of households with the lowest incomes;

6) market capacity of certain products that tracked in dynamics and determined in terms of quantity as the product of a particular product consumption and the average population according to the formula:

$$
V_{i}=F_{i} N
$$

where $V_{i}$ - the capacity of the domestic market of the $i$-product; $i$-a type of the $i$-product; $F_{i}$ - annual average consumption of the $i$-product; and $N$ - average annual population;

7) food self-sufficiency for a certain product, defined as the ratio between the volume of imports of a particular product in terms of quantity and capacity of its domestic market by the formula:

$$
P=\frac{I_{i}}{V_{i}}
$$

where $P$ - the share of food import of the $i$-product; $i-$ a type of the $i$-product; $I_{i}-$ import of the $i$-product; $V_{i}$ the capacity of the domestic market of the $i$-product ${ }^{3}$.

\section{The daily energy value of the human diet}

Since 1990, the average daily calorie intake of food by the population of Ukraine per capita constantly exceeded the threshold. In 2015, average daily nutritional intake of average Ukrainian was $2799 \mathrm{kcal}$, which is $11.2 \%$ higher than the threshold criterion (2500 kcal). Compared to 1990, calorie intake by the population of Ukraine decreased by $22.2 \%$ (Figure 1).

However, since 1990 the average daily calorie consumption of plant products exceeded the threshold, and the average daily calorie intake of animal products constantly observed deficit. Instead, only $28.3 \%$ of the average daily diet is provided by the consumption of animal products, which is $21.7 \%$ below the set threshold criterion (55\%). Thus, according to the proposed by O.V. Kochetkov and R. V. Makarov (2002), the classification of food security of the population in Ukraine meets the third minimum level (2300-2800 kcal per capita), which provides for such volumes of food resources that make impossible the emergence of hunger, and that should be considered within planning the provision of population with food in emergency (crisis) conditions.

It is obvious replacing of "expensive" calories by "cheapest one", which allows satisfying energy demand but does not ensure intake of all essential trace elements, vitamins, and minerals. As a result, there is another problem of food security - overeating and obesity.

Deficient food diets can lead to the growth of obesity and diet-related, non-communicable diseases that are increasingly distributed among the poor people. It was found that obesity is associated with the lack of food security in a number of adults' groups and is associated

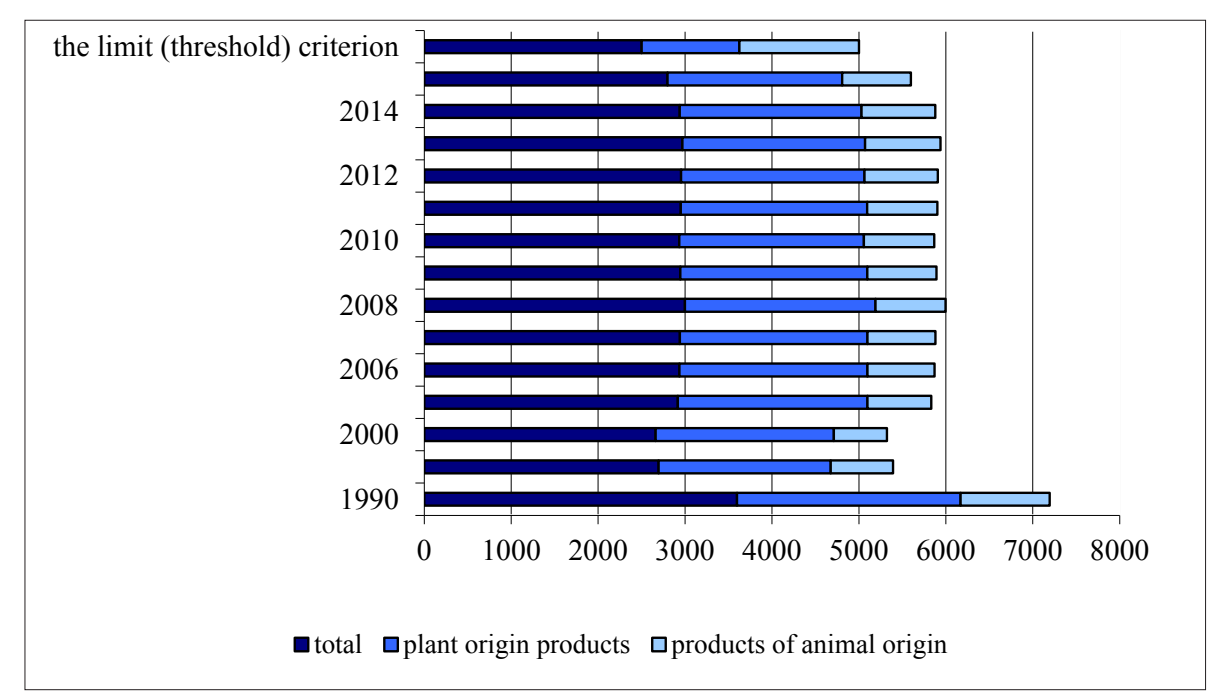

Figure 1. Dynamics of the average daily calorie intake of food in Ukraine per capita, kcal per day

Source: own calculations based on data from ukrstat.gov.ua

\footnotetext{
${ }^{3}$ limit (threshold) criterion for this indicator is its 30-percent level
} 
with poverty. The coexistence of malnutrition and excessive eating significantly affected the countries that conduct rapid transformation and lay them on the double burden of malnutrition (FAO, 2014). These countries, in particular, include also Ukraine.

\section{Sufficiency of single product consumption}

Optimum is a situation where the actual consumption of food by a person during the year matches a rational norm (tentative set of basic food commodities and food security in average per capita in Ukraine for 20052015), to wit the ratio between the actual and rational consumption is 1 .

In 2015 in Ukraine, compared to 2013-2014 years, the actual consumption of major products by $20 \%$ position was located above or at the level of rational norms. Stable positive dynamics is only in two product groups: grain products and potatoes (except in 1995) (Table 1).

As in previous years, actual consumption lags behind the rational norms consumption of animal products: milk and dairy products - by $44.8 \%$, meat and meat products - by $46.4 \%$. It should be noted that the discrepancy between actual consumption of animal products (except eggs) and norms of rational consumption is primarily due to a decrease in livestock production per person.

In 2015, as in previous years, the deficit of fruits, berries and grapes (43.4\%), fish and fish products (57.0\%), sugar $(6,1 \%)$ consumption is set. In addition, in 2015, in contrast to the 2013-2014 years, there is found insufficient, compared with rational norms, consumption of eggs (3.4\% lower), vegetables and melons food crops ( $0.1 \%$ lower $)$, and vegetable oil of all kinds (5.4\% lower).

The deficiency of basic food groups' consumption particularly has a negative impact on children. If the child is faced with food insecurity, most likely, it will lag in the growth and suffer on disorders of the digestive system, which often precede irreversible consequences lag in growth (FAO, 2016; Fram, 2015). Regarding the links between personal experience of food insecurity and overweight among children, the evidence compelling enough, although a range of other harmful consequences of food insecurity for children, including less healthy diets and negative psychosocial consequences have been well studied (IOM, 2011).

\section{The adequacy of supplies of grain in state resources}

At the beginning of 2015, the state intervention fund accounted for 516.1 thousand tons of grain and leguminous crops (Agrarian Fund, 2016), the amount of average annual domestic consumption of bread and bread products in terms of grain, according to statistics, amounted to 5897.0 thousand tons (ukrstat, 2016). Accordingly, the indicator of sufficiency of grain reserves amounted to $8.6 \%$, which is inconsistent with the provisions of the Law of Ukraine "On State Support of Agriculture of Ukraine” (rada.gov, 2004), Article 9 of which stipulates that the state intervention fund should be formed in the amount of at least 20 percent of domestic consumption. In addition, this indicator is less for $8.4 \%$ of the limit (threshold) criterion for these indices (according to test methods of basic indicators of food security) in $17 \%$, corresponding to 60 days of consumption.

\section{Economic availability of food}

According to the State Statistics Service of Ukraine in 2015, total expenditure of households on food amounted to 2207.23 UAH per month against 1766.14 UAH in 2014 (Table 2).

Table 1

Calculation of the adequacy indicator of food consumption per person per year, kilograms

\begin{tabular}{|l|c|c|c|c|c|c|c|c|c|c|c|}
\hline \multirow{2}{*}{ Type of product } & Rational & \multicolumn{4}{|c|}{ Actual consumption } & \multicolumn{4}{c|}{ Indicator of adequacy of consumption } \\
\cline { 3 - 14 } & rate $^{*}$ & 1995 & 2000 & 2013 & 2014 & 2015 & 1995 & 2000 & 2013 & 2014 & 2015 \\
\hline Bread products & 101,0 & 128,4 & 124,9 & 108,4 & 108,5 & 103,2 & 1,271 & 1,237 & 1,073 & 1,073 & 1,022 \\
\hline Meat and meat products & 80,0 & 38,9 & 32,8 & 56,1 & 54,1 & 50,9 & 0,486 & 0,410 & 0,701 & 0,686 & 0,636 \\
\hline Milk and milk products & 380,0 & 243,6 & 199,1 & 220,9 & 222,8 & 209,9 & 0,641 & 0,524 & 0,581 & 0,586 & 0,552 \\
\hline Fish and fish products & 20,0 & 3,6 & 8,4 & 14,6 & 11,1 & 8,6 & 0,180 & 0,420 & 0,730 & 0,540 & 0,430 \\
\hline Eggs (pcs.) & 290 & 171 & 166 & 309 & 310 & 280 & 0,590 & 0,572 & 1,066 & 1,072 & 0,965 \\
\hline $\begin{array}{l}\text { Vegetables and melons food } \\
\text { crops }\end{array}$ & 161,0 & 96,7 & 101,7 & 163,3 & 163,2 & 160,8 & 0,601 & 0,632 & 1,014 & 1,013 & 0,999 \\
\hline $\begin{array}{l}\text { The fruits, berries and grapes } \\
\text { (excluding wine) }\end{array}$ & 90,0 & 33,4 & 29,3 & 56,3 & 52,3 & 50,9 & 0,371 & 0,326 & 0,626 & 0,600 & 0,566 \\
\hline Potato & 124,0 & 123,8 & 135,4 & 135,4 & 141,0 & 137,5 & 0,998 & 1,092 & 1,092 & 1,169 & 1,109 \\
\hline Sugar & 38,0 & 31,6 & 36,8 & 37,1 & 36,3 & 35,7 & 0,832 & 0,968 & 0,976 & 0,961 & 0,939 \\
\hline Vegetable oil of all kinds & 13,0 & 8,2 & 9,4 & 13,3 & 13,1 & 12,3 & 0,631 & 0,723 & 1,023 & 1,062 & 0,946 \\
\hline
\end{tabular}

* calculation of the Ministry of Health of Ukraine

Source: own calculations based on data from ukrstat.gov.ua 
Table 2

Expenditures on food and non-alcoholic drinks, UAH per month

\begin{tabular}{|l|c|c|c|}
\hline \multicolumn{1}{|c|}{ Indicator } & 2014 & 2015 & $\begin{array}{c}2015 \text { to } \\
2014(\%)\end{array}$ \\
\hline An average per household & 1766,14 & 2207,23 & 125,0 \\
\hline in \% to consumer expenditures & 52,9 & 54,0 & 1,1 \\
\hline in \% to monetary expenditures & 47,8 & 49,6 & 1,8 \\
\hline In urban areas & 1960,21 & 2432,01 & 124,1 \\
\hline in \% to monetary expenditures & 49,4 & 51,3 & 1,9 \\
\hline - in big cities & 2093,19 & 2628,29 & 125,6 \\
\hline in \% to monetary expenditures & 49,1 & 50,9 & 1,8 \\
\hline - in small towns & 1761,59 & 2157,30 & 122,5 \\
\hline in \% to monetary expenditures & 50,0 & 51,9 & 1,9 \\
\hline In rural areas & 1375,64 & 1747,34 & 127,0 \\
\hline in \% to monetary expenditures & 43,7 & 45,4 & 1,7 \\
\hline
\end{tabular}

Source: own calculations based on data from ukrstat.gov.ua

However, there was set a fluctuation of this indicator in terms of households' categories in urban and rural areas - respectively 51.3 and $45.4 \%$. This is explained by the fact that in most of the rural settlements, households produce food by their own, and therefore - do not spend money on its purchase. On the contrary, the vast majority of the rural population is trying to get additional revenue due to the implementation of food received in their own household.

In the regions of Ukraine, there is also observed heterogeneity share of monetary household expenditures on food and non-alcoholic drinks: the lower in Zakarpattia Region, higher - in Dnipropetrovsk Region. Relatively low level of the expenditure on food (by their share in the total amount of monetary expenditures) is observed in Zakarpattia Region, Chernivtsi Region, Sumy Region, Ivano-Frankivsk Region, and Luhansk Region; critical level - in Dnipropetrovsk Region, Odesa Region, Kherson Region, and Lviv Region (Figure 2).

Moreover, both increase and decrease of the expenditure on food proportion can have both positive and negative reasons and consequences. On the one hand, reducing expenditure on food share, which in itself reflects the positive momentum of indicator, may mean that consumers in the region produced a greater share of food by themselves (subsistence) or households' income is higher (ceteris paribus), or food in the region is cheaper. On the other hand, such dynamics may indicate the lowest adequacy of an indicator of basic food kinds' consumption in the region.

Thus, the indicator of the availability of food last year was $49.6 \%$ at its 60 percentage limit criteria. Compared to the previous year, this figure declined by 1.9 percentage points.

It should be noted a significant influence on the choice of certain food of preferences and traditional habits of certain types of products eating. Comparison of the provision of basic food products indicator with the share spent on them in total food expenditures shows that almost the highest and lowest unit costs in

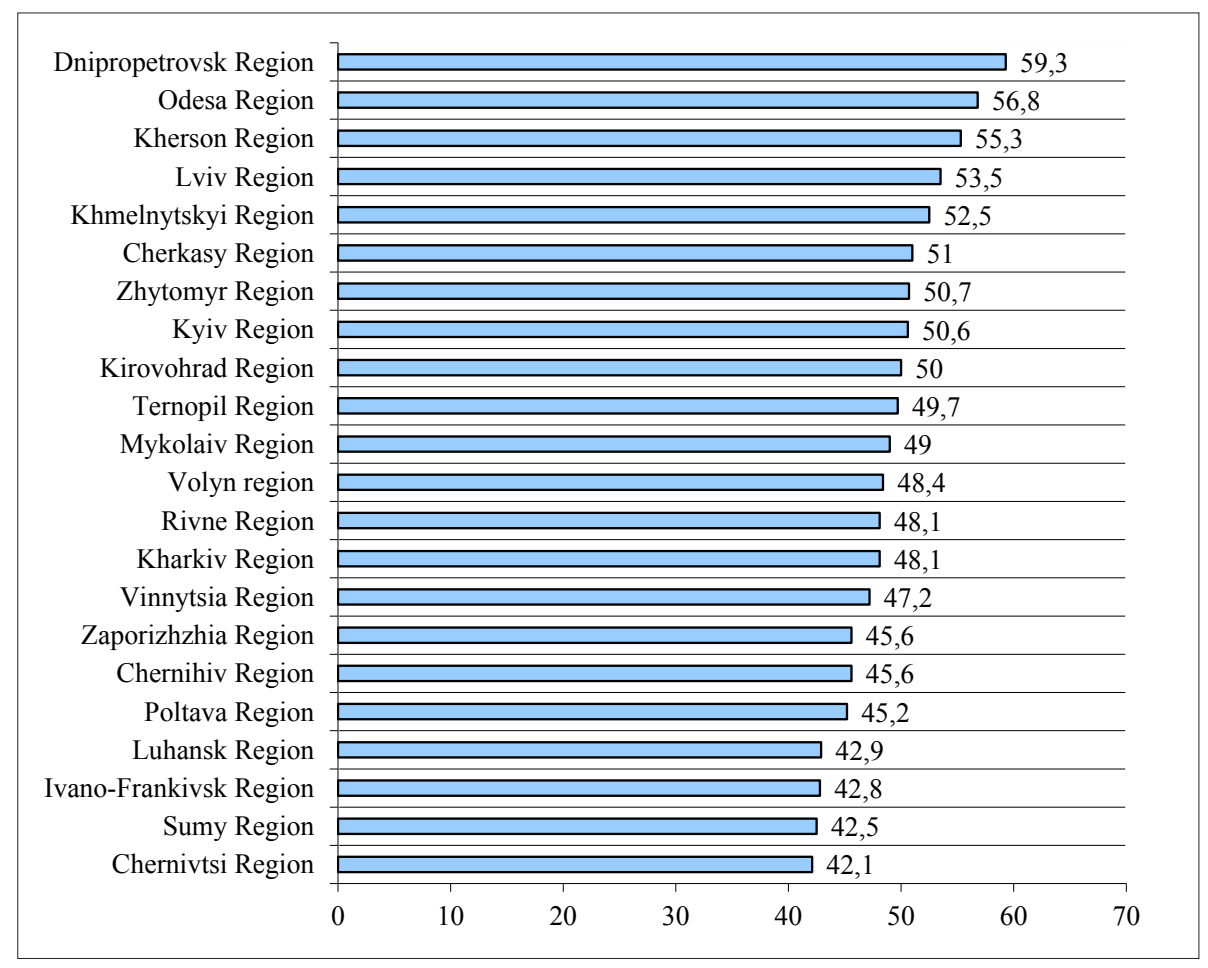

Figure 2. The share of monetary household expenditures on food and non-alcoholic beverages by the region of Ukraine, \%

Source: own calculations based on data from ukrstat.gov.ua 


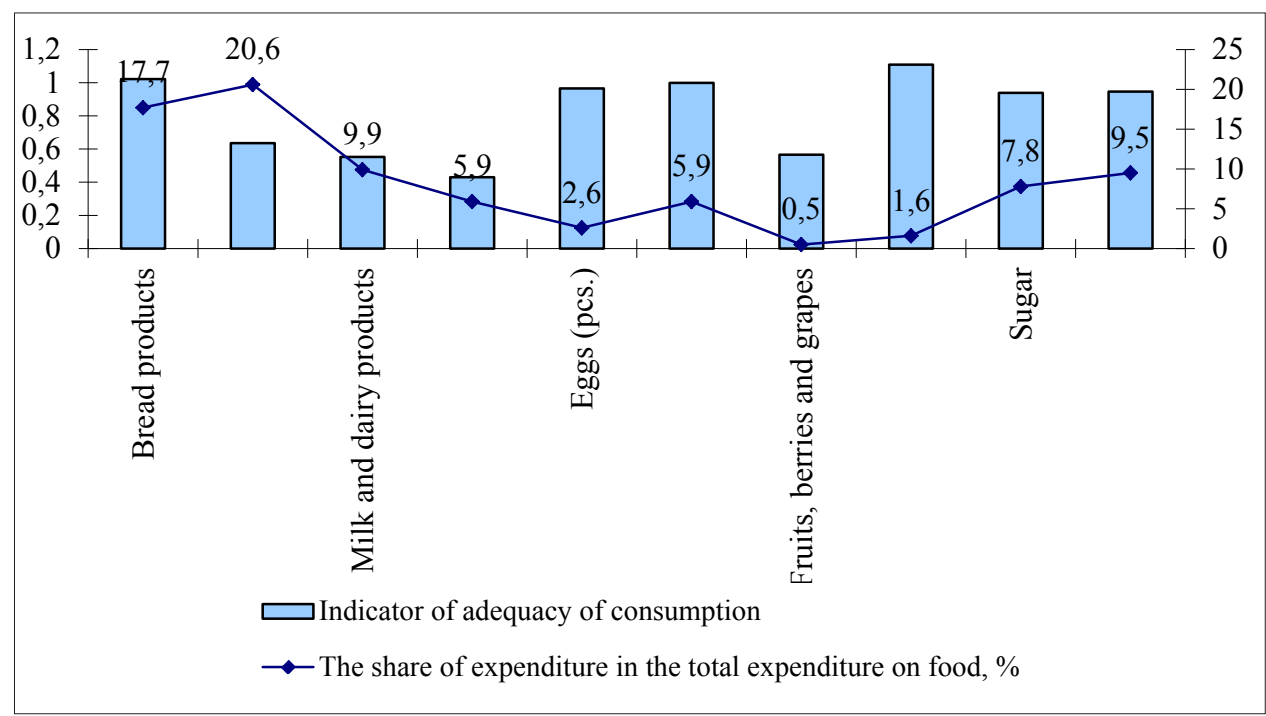

Figure 3. Comparing the share of expenditure in the total expenditure on food sufficiency indicator of consumption in 2015

Source: own calculations based on data from ukrstat.gov.ua

accordance to grain products $(17.7 \%)$ and potatoes (1.6\%). That is, exactly, those kinds of products on which rational consumption rates achieved, while the consumption of potatoes rational rate $22.8 \%$ over the bread products indicator. The same applies to the food, which is almost the worst (except fish) consumption adequacy indicators: the proportion of spending on meat and meat products and fruits, berries and grapes are respectively 20.6 and $0.5 \%$ (Figure 3 ).

\section{Food cost differentiation for social groups}

According to the State Statistics Service of Ukraine in 2015, 10 percent of households with the highest incomes on average spent on food $2822.06 \mathrm{UAH}$ per month, and 10 percent of households with the lowest incomes - $1653.68 \mathrm{UAH}$.
Food cost differentiation factor for social groups was 1.71 versus 1.48 in 2014, i.e., during the study period, there was a slight decrease in the differentiation of social groups in terms of food spending.

\section{The capacity of the domestic market of certain products}

Compared with 1995, in 2015, there was an increase in capacity of the domestic market in the following food groups: meat and meat products - by $8.3 \%$, fish and fish products - by $97.2 \%$, eggs - to $35.9 \%$, vegetables and melons food crops $-37.7 \%$, fruits, berries and grapes by $26.1 \%$, oil - by $23.8 \%$ (Table 3 ).

At the same time, the largest deviations between actual and estimated market size for the rational consumption norms are established by groups of such food as meat

Table 3

Assessment of the capacity of the domestic market, ths. tons

\begin{tabular}{|c|c|c|c|c|c|c|c|}
\hline \multirow{3}{*}{ Type of product } & \multicolumn{7}{|c|}{ Domestic market capacity } \\
\hline & \multicolumn{4}{|c|}{ actual } & \multicolumn{3}{|c|}{ subject to rational consumption norms } \\
\hline & 1995 & 2000 & 2015 & $\begin{array}{c}2015 \text { in } \% \\
\text { to } 1995\end{array}$ & 1995 & 2000 & 2015 \\
\hline Bread products & 6641,9 & 6173,8 & 4422,8 & 66,6 & 5224,6 & 4992,4 & 4318,8 \\
\hline Meat and meat products & 2012,2 & 1621,3 & 2178,7 & 108,3 & 4138,3 & 3954,4 & 3420,8 \\
\hline Milk and milk products & 12601,0 & 9841,5 & 8995,0 & 71,4 & 19656,8 & 18783,3 & 16249,0 \\
\hline Fish and fish products & 186,2 & 415,2 & 367,2 & 197,2 & 1034,6 & 988,6 & 855,2 \\
\hline Eggs & 510,8 & 473,9 & 694,0 & 135,9 & 868,2 & 827,8 & 684,2 \\
\hline Vegetables and melons food crops & 5002,1 & 5027,0 & 6889,8 & 137,7 & 8328,3 & 7958,2 & 6884,4 \\
\hline $\begin{array}{l}\text { Fruits, berries and grapes } \\
\text { (excluding wine) }\end{array}$ & 1727,7 & 1448,3 & 2178,9 & 126,1 & 4655,6 & 4448,7 & 3848,4 \\
\hline Potato & 6404,0 & 6692,8 & 5891,5 & 99,0 & 6414,3 & 6129,3 & 5302,3 \\
\hline Sugar & 1634,6 & 1819,0 & 1527,6 & 93,5 & 1965,7 & 1878,3 & 1624,9 \\
\hline Vegetable oil of all kinds & 424,2 & 464,6 & 525,1 & 123,8 & 672,5 & 642,6 & 555,9 \\
\hline
\end{tabular}

Source: own calculations based on data from ukrstat.gov.ua 
Table 4

Calculation of dependence on imported food groups

\begin{tabular}{|c|c|c|c|c|c|c|c|c|c|c|}
\hline \multirow{2}{*}{ Type of product } & \multicolumn{5}{|c|}{ Import of products, thousand tons } & \multicolumn{5}{|c|}{ Dependence on imported food, $\%$} \\
\hline & 1995 & 2000 & 2013 & 2014 & 2015 & 1995 & 2000 & 2013 & 2014 & 2015 \\
\hline Bread products & 200 & 1010 & 242 & 263 & 190 & 3,0 & 16,4 & 4,9 & 5,6 & 4,3 \\
\hline Meat and meat products & 19 & 38 & 332 & 201 & 158 & 0,9 & 2,3 & 13,0 & 8,6 & 7,3 \\
\hline Milk and dairy products & 58 & 50 & 548 & 357 & 78 & 0,5 & 0,5 & 5,4 & 3,7 & 0,9 \\
\hline Fish and fish products & 5 & 2 & - & - & - & 1,0 & 0,4 & - & - & - \\
\hline Eggs & 41 & 29 & 5 & 7 & 11 & 0,8 & 0,6 & 0,6 & 0,9 & 0,2 \\
\hline Vegetables and melons food crops & 309 & 179 & 237 & 225 & 95 & 17,9 & 12,4 & 3,2 & 3,2 & 1,4 \\
\hline $\begin{array}{l}\text { Fruits, berries and grapes (without } \\
\text { reprocessing into wine) }\end{array}$ & 126 & 11 & 1172 & 856 & 588 & 2,0 & 0,2 & 45,7 & 38,1 & 27,0 \\
\hline Potatoes & 123 & 177 & 23 & 40 & 17 & 7,5 & 9,7 & 0,4 & 0,7 & 0,3 \\
\hline Sugar & - & - & 11 & 7 & 4 & - & - & 0,7 & 0,4 & 0,3 \\
\hline Vegetable oil of all kinds & - & - & 296 & 223 & 160 & - & - & 48,9 & 39,7 & 30,5 \\
\hline
\end{tabular}

Source: own calculations based on data from ukrstat.gov.ua

and meat products $-36.3 \%$, milk and dairy products $44.6 \%$, fruits, berries and grapes $-57.1 \%$, sugar $-6.0 \%$.

\section{Food self-sufficiency for a certain product}

Meeting the needs of the population for food, within its purchasing power in 2014, as in previous years, is carried out mainly by domestic products (Table 4 ).

The most vulnerable positions in terms of dependence on imported positions are "fruits, berries and grapes" and "all kinds of vegetable oil", the share of imports by these groups in the total consumption is respectively 27.0 and $30.5 \%$ at 30 percentage threshold criteria for this indicator.

\section{Conclusions}

The state of Food Security in 2015 in Ukraine by most standards satisfies set thresholds and rules. The values of individual indicators, calculated according to 2015 compared to 1995, positively characterize the dynamics of food security of Ukraine:

- found a significant increase in diets of Ukrainians of those types of food, consumption of which is lagging behind most rational norms (meat and fish products), almost all types of products improved adequacy of consumption;
- needs of the population in food carried out mainly by domestic agricultural products;

- in Ukraine, there is a high self-sufficiency of population for the main types of food.

At the same time, the state of food security of Ukraine cannot be characterized as stable positive:

- for products of animal origin, decreased average daily caloric intake of the population;

- worsened the accessibility of food for the population; - adequacylevels of the grain supplies in state resources is lower compared to the maximum prescribed limit;

- set high level of food dependency (in terms of the rational norms of consumption) for meat, milk and fish products, fruits, berries and grapes;

- greatly exceeds the threshold percentage of import dependence of Ukraine on fruits, berries and grapes, and compared to 1995 given indicator increased by 25.0 percentage points.

Ukraine with available resources, according to various researchers, can "feed" about 100-150 million people (Kotykova, 2010). Instead, there is a paradoxical situation, when country for export of raw materials (sunflower) is consistently among the top five world leaders and still has $40 \%$ of the value indicator depending on imported oil. Obvious is the need for a balanced state policy regulating the domestic market and the agricultural sector.

\section{References:}

Balances and consumption of basic foodstuffs by population of Ukraine for 2015 (2016). In O.M. Prokopenko (Ed.). Kyiv: August Trade (in Ukr.). Retrieved from: http://www.ukrstat.gov.ua/

Costs and resources of households in Ukraine in 2015 (2016). In I. Osipova (Ed.). Kyiv: August Trade (in Ukr.)

FAO (2014). The State of Food Insecurity in the world - 2014. Improving the enabling environment for food security and nutrition, Retrieved from: http://www.fao.org/3/a-i4646r.pdf

FAO (2016). Methods for estimating comparable rates of food insecurity experienced by adults throughout the world. Rome, FAO (see page 28).

FAO (2016). Monitoring food security and nutrition in support of the implementation of the Agenda for sustainable development till 2030: Conclusions and future plans. Retrieved from: http://www.fao.org/3/a-i6188r.pdf

FAO (2017). Food security statistics. Retrieved from: http://www.fao.org/economic/ess/ess-fs/ess-fadata/en/\#. WIT09PCLS00 
Fram, M.S., Bernal, J. \& Frongillo E.A. (2015). The Measurement of Food Insecurity among Children: Review of literature and concept note, Innocenti Working, Paper No.2015-08, UNICEF Office of Research, Florence.

IOM (Institute of Medicine) (2011). Hunger and Obesity: Understanding a Food Insecurity Paradigm: Workshop Summary. Washington, DC: The National Academies Press.

Jessica Fanzo (2015). Ethical issues for human nutrition in the context of global food security and sustainable development (Global Food Security), 7, 15-23, ISSN 2211-9124, http://dx.doi.org/10.1016/j.gfs.2015.11.001.

John Wilkinson (2015). Food security and the global agrifood system: Ethical issues in historical and sociological perspective (Global Food Security), 7, 9-14, ISSN 2211-9124, http://dx.doi.org/10.1016/j.gfs.2015.12.001.

Kathryn J. Fiorella, Rona L. Chen, Erin M. Milner, Lia C.H. Fernald (2016). Agricultural interventions for improved nutrition: A review of livelihood and environmental dimensions (Global Food Security), 8, 39-47, ISSN 2211-9124, http://dx.doi.org/10.1016/j.gfs.2016.03.003.

Kochetkov, O. V. (2002). Formation of food security indicators of Ukraine (Ekonomika APK), 9, 142-158 (in Ukr.)

Kotykova, O. I. (2010). Grounding and realization of land resources management principles as a way to maintain stable development of land tenure (Actual problem of economics), 1 (103), 75-79 (in Ukr.)

On food security of Ukraine (2011). The electronic catalog of Verkhovna Rada of Ukraine (Draft of the Law of Ukraine). Retrieved from: http://w1.c1.rada.gov.ua/pls/zweb2/webproc4_2?pf3516=8370-1\&skl=7

On State Support of Agriculture of Ukraine (2004). The electronic catalog of Verkhovna Rada of Ukraine (Law of Ukraine). Retrieved from: http://zakon2.rada.gov.ua/laws/show/1877-15

Sarina Macfadyen, Jason M. Tylianakis, Deborah K. Letourneau, Tim G. Benton, Pablo Tittonell, Michael P. Perring, Carla Gómez-Creutzberg, András Báldi, John M. Holland, Linda Broadhurst, Kimiko Okabe, Anna R. Renwick, Barbara Gemmill-Herren, Henrik G. Smith (2015). The role of food retailers in improving resilience in global food supply (Global Food Security), 7, 1-8, ISSN 2211-9124, http://dx.doi.org/10.1016/j.gfs.2016.01.001.

Some issues of food security (2007). The electronic catalog of Verkhovna Rada of Ukraine (The Cabinet of Ministers of Ukraine Resolution). Retrieved from: http://zakon4.rada.gov.ua/laws/show/1379-2007-\%D0\%BF

The Profit of "Agrarian Fund" in 2016 amounted to 48.7 million USD [Electronic resource] / Text from the screen. - Retrieved from: http://agravery.com/uk/posts/show/pributok-agrarnogo-fondu-za-2016-rik-sklav-487mln-griven

Zhengxia Dou, James D. Ferguson, David T. Galligan, Alan M. Kelly, Steven M. Finn, Robert Giegengack, Assessing U.S. (2016). Food wastage and opportunities for reduction (Global Food Security), 8, 19-26, ISSN 2211-9124, http://dx.doi.org/10.1016/j.gfs.2016.02.001. 